\title{
Routledge Handbook of Public Communication of Science and Technology
}

Edited by Massimiano Bucchi and Brian Trench

First published 2008

ISBN: 978-0-367-48312-8 (hbk)

ISBN: 978-1-003-03924-2 (ebk)

Chapter 8

\section{Mediatisation of science and the rise of promotional culture}

Esa Väliverronen

(CC-BY-NC-ND 4.0)

DOI: $10.4324 / 9781003039242-8$

The funder for this chapter is University of Helsinki

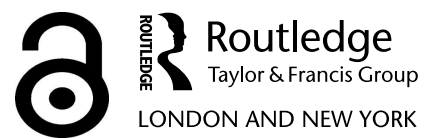




\title{
Mediatisation of science and the rise of promotional culture
}

\author{
Esa Väliverronen
}

\section{Introduction}

This chapter reviews the mediatisation concept, which has recently made a strong impact in media and communication studies, particularly in the field of political communication but also in science communication. It discusses the outcomes and problems of mediatisation research in relation to shifting science communication practices. The chapter introduces the concept of promotional culture in order to put the mediatisation of science into the broader social and cultural context of commercialisation and marketisation of research and universities.

'Mediatisation' became perhaps the most popular concept in media research in the 2010s (Corner 2018; Nowak-Teter 2019), discussed in numerous conferences, seminar groups, books, articles and case studies devoted to the subject. Although it was sporadically used in different contexts in the 1980s and 1990s (e.g., Asp 1986, 1990; Martín-Barbero 1993; Thompson 1995; Mazzoleni and Schulz 1999), it was later named a 'key concept' (Lundby 2009), indicating a 'paradigm shift' (Hepp et al. 2015: 315) in media and communication studies. The concept has appeared in different forms - mediasation, medialisation and mediatisation - but 'the most likely "winner" in a race between many terms, all cumbersome and ambitious' (Couldry and Hepp 2013: 191) is mediatisation.

In the beginning, the term was particularly popular in the Nordic countries, Germany and Central Europe. In the English-speaking world, this somewhat 'clumsy neologism' (Livingstone 2009: 6) has also aroused considerable interest. However, there have been discussions on whether 'mediation' should be used instead of mediatisation (e.g., Silverstone 2005). Recently, however, mediatisation has become increasingly accepted. The popularity of the new buzzword has also aroused considerable criticism in the field of media research, particularly about the concept's ambiguity and media-centredness (e.g., Adolf 2015; Ampuja et al. 2014; Corner 
2018; Deacon and Stanyer 2014; Lunt and Livingstone 2016). However, the concept's proponents have been very productive, creating numerous books and case studies, and they have even proposed a new stage, called 'deep mediatisation' (Hepp and Hasebrink 2018).

At a descriptive level, it is easy to subscribe to the idea of mediatisation. Different means of communication have become omnipresent in contemporary society. The emergence of the Internet and various social media platforms has made producing and circulating media content relatively easy. The technological possibilities offered by different media are more diverse than before. The media are more mobile than ever. They are an organic part of everyday life for more and more people and may affect highly specialised activities such as science and technology communication. Although mediatisation has attracted much interest, there is no unified understanding of the concept, even among its main advocates.

Perhaps we can say that mediatisation has become an ambitious umbrella concept (Ampuja et al. 2014: 112) that takes society and culture as a whole as the target. In general, the concept of mediatisation tries to capture long-term processes of the interrelation between media change on the one hand and social and cultural change on the other (Hepp et al. 2010: 223). Not all mediatisation advocates assume that the media constitute the social and cultural world's dominant centre (see e.g., Krotz 2009). Nevertheless, they do tend to agree that the media have become increasingly important, or even decisive, for all social and cultural spheres and institutions (e.g., Krotz 2009: 24; Hjarvard 2008).

This chapter argues that instead of limiting the analysis to the supposed 'media power' vis a vis other institutions such as politics or science, we should focus on the broader changes in society such as commercialisation, individualisation and the rise of promotional cultures. The supposed 'media logic' affecting institutions is in fact intertwined with many other institutional logics in society, such as advertising, PR and marketing. Further, we should acknowledge the plurality of media and the multifaceted nature of our current communication and media environment where numerous actors and power brokers compete in the management of public visibility.

\section{Different perspectives in mediatisation research}

Mediatisation has been applied to thinking about the evolving position of science in society, including by leading scholars in the field of science communication (e.g., Weingart 1998, 2012; Peters et al. 2008a; Peters 2012; Rödder 2009; Rödder and Schäfer 2010). This will be considered in detail later but, first, we examine research on mediatisation in general, and in politics, in particular.

Research on mediatisation forms a diverse field of study, in which the concept often works as an umbrella term for theoretical discussions and case studies. For instance, Krotz (2009: 29) has made a distinction between a functionalist (Mazzoleni and Schulz 1999) and a cultural or social perspective. In a partly similar vein, Couldry and Hepp (2013: 196) have distinguished an institutionalist from a social-constructivist tradition. While the institutional perspective focuses on how institutions are affected by media institutions (e.g., Hjarvard 2013), the 
social-constructionist perspective is more interested in how the media contribute to the constitution of the daily practices of the social world (e.g., Hepp 2013b; Couldry and Hepp 2013). According to Deacon and Stanyer (2014), in institutionalist accounts (e.g., Mazzoleni and Schulz 1999; Hjarvard 2008), mediatisation is seen on the one hand as a process in which non-media social actors have to adapt to 'media's rules, aims, production logics, and constraints'. On the other hand, in socialconstructivist accounts (Hepp 2013: 616; see also Couldry and Hepp 2013; Krotz 2009), mediatisation is seen more as a process in which changing communication and media technologies contribute to 'the changing communicative construction of culture and society'.

These different approaches make visible that the word 'media' has many different meanings in mediatisation research. Institutionalist accounts often refer to "'big" media organisations and their centripetal power' and social-constructivist accounts to 'the "small" media and their centrifugal presence' (Deacon and Stanyer 2014: 1033). Institutional accounts usually refer to the concept of 'media logic' by Altheide and Snow (1979) and constructivist accounts to medium theorists such as Innis and McLuhan (see Lundby 2009). Further, while some scholars of mediatisation of politics have discussed media functions and referred to system theory (e.g., Kunelius and Reunanen 2012; Meyen et al. 2014), Hjarvard (2013), one of the main proponents of an institutional perspective, leans more towards structuration than system theory (Andersson 2017: 37).

Further, Ampuja et al. (2014) have distinguished between two forms of mediatisation theory: a strong form based on the assumption that a 'media logic' increasingly determines the actions of different social institutions and groups and a weak form that questions such logic. The latter form emphasises the key role of the media in social change and singles out mediatisation as a central 'meta-process' today.

The strong version of mediatisation was particularly visible in the early accounts of the new paradigm's proponents. The starting point for a strong version of mediatisation theory is the argument that contemporary societies have become 'permeated by the media' (Hjarvard 2008, 105). This constitutes a 'new social condition' (p. 224) that Hjarvard (2008) has called 'the mediatization of society'.

\section{New paradigm or heuristic concept}

An important question raised in the debate on mediatisation research is "whether mediatisation has already become a paradigm that offers its representatives a theoretical problematic or a set of presuppositions, questions and interpretations' (Ampuja et al. 2014: 113). This has created heated debates among media and communication scholars, for instance in the journal Media, Culture and Society (see Deacon and Stanyer 2014, 2015; Hepp et al. 2015; Lunt and Livingstone 2016; Ekström et al. 2016).

Critics of mediatisation theory have claimed that it refers to a meta-process that is so complex that it eventually tends to incorporate anything. For instance, Deacon and Stanyer $(2014,2015)$ have argued that mediatisation runs the risk of becoming a 'concept of no difference' that 'encompasses and conflates a vast range of media and 
communication structures, processes and practices' (Deacon and Stanyer 2015: 657). In their critical review, Deacon and Stanyer $(2014,2015)$ have argued that mediatisation has remained a rather ambivalent concept: 'While most authors see mediatization as a continuous process emerging over a long period of time, there is little consensus on when it started and some even suggest it might have ended'. According to Deacon and Stanyer, mediatisation is often understood in too simplistic ways. It is an account of change that is driven by a narrow set of causal variables - the mass media or ICTs - that are seen as powerful enough on their own to bring about change over time. Conversely, the 'role of non-media factors in jointly influencing changing communicative practice is largely overlooked' (Deacon and Stanyer 2014: 1034).

In contrast, Livingstone and Lunt have provided a more sympathetic reading of mediatisation research as a 'sensitising concept' (Livingstone and Lunt 2014) or promising 'research programme' (Lunt and Livingstone 2016). While subscribing to part of the critique on the ambiguity of the concept and paradigmatic change, they have argued that 'sceptics of mediatisation' have been too eager to dismiss the term as useless. Lunt and Livingstone $(2016,464)$ 'find it more constructive to conceive of mediatization as a sensitising concept that offers 'a general sense of reference and guidance in approaching empirical instances', sensitizing the researcher about where to look rather than defining precisely what exists in advance'. The concept may help sensitise media researchers to a new historical awareness of various transformations in a variety of social domains and 'the intersections among metaprocesses in the larger analysis of modernity', such as 'globalization or individualization or commercialization or rationalization or democratization or urbanization (p. 465).

Another constructive criticism has come from Ekström et al. (2016). They subscribe to the heuristic value of the mediatisation concept but argue 'mediatization researchers have sometimes formulated too grand claims as to mediatization's status as a unitary approach, a meta-theory or a paradigm' (p. 1090). Instead of totalising claims of mediatisation and media power, they call for more historicity, specificity and measurability. Too much research has hypostasised the existence of mediatisation as a linear process, without considering how mediatisation interacts with other processes of social change.

\section{Mediatisation of politics}

The scope of mediatisation research has increased considerably over the years. At its inception, the concept targeted specific processes, especially the mediatisation of politics. However, the 'concept has already demonstrated remarkable portability, with discussions about, inter alia, the mediatisation of politics, war, religion, medicine, science, music, identity construction, health, childhood, theatre, tourism, memory, climate change, policy making, performance, consumption, madness, death, intimate relationships, human geography and education' (Deacon and Stanyer 2014: 1032).

The concept of mediatisation has been most commonly used in describing the transformation of politics and political communication. It has been argued that not 
only have the media taken an increasing role in the opinion-building process but also that the media have become the most important arena for politics. Already in the late 1980s, Swedish political scientist Kenneth Asp (1986: 380; 1990) argued that 'the political actors have, to a great extent, adapted to the requirements which the mass media place on their coverage of the political world'. Asp described this process as the 'medialisation of politics'.

Later, this idea was developed further by Mazzoleni and Schulz (1999), perhaps the most cited scholars in mediatisation research (Nowak-Teter 2019: 6). According to Mazzoleni and Schulz (1999, 250), 'mediatized politics is politics that has lost its autonomy, has become dependent in its central functions on mass media, and is continuously shaped by interactions with mass media'. They pointed to a development where political institutions, leaders and practices become increasingly dependent upon media and conform to the logics of media production, distribution and reception (Mazzoleni and Schulz 1999; Esser and Strömbäck 2014; Flew 2017). Thus, politicians have become increasingly focused upon how their actions may play out in the media. It has been argued that media institutions have a capacity to shape the political agenda. Political actors have to compete for attention in the news with celebrities and other actors in order to 'gain control over the media' (Mazzoleni and Schulz 1999: 252). The mediatisation of politics thesis has been associated with political leaders such as Bill Clinton and Tony Blair, who promoted 'postideological' politics (Flew 2017: 52).

One of the most popular classifications makes a distinction between four phases in the process of the mediatisation of politics (Strömbäck 2011; Strömbäck and Esser 2014). These phases illustrate the increasing dependency of political institutions on the media. In the first phase, the media are the most important source of information about politics and society in general. In the second phase, the media achieve the status of a (semi-)independent institution influencing social and political institutions. In the third stage, media content becomes mainly governed by media logic, which is replacing political logic. Finally, in the fourth phase, political institutions and actors are governed by media logic instead of political logic.

However, the mediatisation process is not unidirectional. Mediatisation leads to the growing dependence of media organisations on market forces. The symbiosis of media logic and commercialisation of media enterprises is confirmed in media studies (Altheide 2013; Ampuja et al. 2014; Nowak-Teter 2019). The late twentieth-century apprehension that the mass media might usurp the function of political institutions does not seem well founded today. In the 2000s and 2010s there have been important developments in both politics and media that indicate the need to modify the mediatisation thesis regarding politics. According to Flew (2017), the rise of the Internet and social media platforms as alternative modes of political communication has been linked to other shifts in politics, such as the rise of populist leaders and movements, for example the election of Donald Trump as an 'outsider' US President in 2016. Thus, if we are interested in the mediatisation of politics and the role of 'media logic', we need to 'register that changes in the overall media ecology can be expected in turn to reshape those relationships' (Flew 2017: 54). 


\section{Research on the mediatisation of science}

The changing relations of science and the media have been conceptualised in terms of mediatisation from the late 1990s (e.g., Weingart 1998, 2001; Väliverronen 2001; Peters et al. 2008a; Peters 2012; Rödder 2009; see also Bucchi and Trench 2014). The main argument is that the mediated public sphere has become an important arena for the public legitimation of science. New ways of managing visibility, such as $\mathrm{PR}$ and other promotional practices, have become a central part of universities and research institutions. These practices affect not only science communication but also the practices of the scientific profession itself (Väliverronen 2001: 163; Trench 2012: 274; Maeseele 2013: 164).

Discussions and case studies on the mediatisation of science have been mainly influenced by system-theoretical or institutional perspectives, partly similar to the studies of the mediatisation of politics. However, many of these studies have not made actual references to mediatisation research and instead have conceptualised the issue as 'medialisation of science' (e.g., Weingart 1998, 2001; Rödder 2009). Franzen et al. (2012: 5) have even argued that 'the term medialization has to be distinguished from the much broader concept of "mediatization". "With mediatisation they seem to refer only to social-constructivist or cultural accounts of mediatisation research. However, the 'medialisation of science' perspective bears many similarities to the institutionalist and system-theoretical accounts of mediatisation research well represented in the studies of mediatisation of politics (see e.g., Peters et al. 2008a; Marcinkowski and Kohring 2014).

The 'medialisation of science' perspective understands mass media 'as a social system with its own logic based on specific selection processes' (Franzen et al. 2012: 5). Peter Weingart has described the process of medialisation as a 'loss of distance' between subsystems of society (Weingart 2001: 124). His main argument is that science has become 'more tightly coupled' with the political, economic and media systems. In his pioneering article, Weingart (1998) argues that, the increasing 'science-media coupling' has led to changes in the ways science is represented in public discourses and science as an institution has become more oriented towards the media. This new orientation is manifested in the staging of media events, the pre-publication of research results in the media prior to their scientific publication and the increasing promotion of scholarly journals to the media.

Weingart (1998; Weingart and Pansegrau 1999) has argued that mediatisation not only influences the public presentation of science but also funding priorities and knowledge production. Weingart has focused on three aspects of the mediatisation process. Firstly, there is an increasing media orientation of research organisations and individual researchers. This is manifested in the competition for public visibility in terms of pre-publication of research in the public media. Secondly, this leads to reputation management by scientists and research organisations. The idea behind this is that public fame is somehow converted into scientific reputation. Thirdly, he argues that increasing media orientation contributes to hyperbolic media discourse such as over-optimistic claims about scientific breakthroughs or the practical utility of research. 
Hans-Peter Peters et al. (2008a) analysed mediatisation of science as a consequence of the mediatisation of politics. They associate the political effects of mediatisation with the legitimisation of science or science organisations. Further, they argued that the 'adoption of media logic creates opportunities to integrate scientific expertise into policymaking' (p. 89). Based on interviews with PR heads of research institutions, however, they conclude 'the empirical evidence points almost exclusively to effects on public self-representation, and hardly to effects on the core of knowledge production. On the contrary, the PR officers emphasized the right of science to autonomy' (p. 89).

While Weingart and Peters prefer the term 'medialisation', others have used the term mediatisation of science and connected the concept to wider mediatisation research (e.g., Rödder and Schäfer 2010; Maeseele 2013; Trench 2012; Väliverronen 2001). Rödder and Schäfer (2010) have analysed the mediatisation of science thesis from the sociology of science perspective, drawing from the institutionalist approach to mediatisation. They distinguish two analytical dimensions of the mediatisation thesis: 'science news coverage, and the repercussions of media attention on science' (Rödder and Schäfer 2010: 249). In relation to the first dimension, previous studies have argued that the media coverage of science has increased (e.g., Bucchi 1998; Nelkin 1995; Schäfer 2009), and it has become more diverse (e.g., Weingart 1998; Weingart 2012). Second, science has become more publicly oriented in order to legitimise its usefulness to society (see e.g., Gregory and Miller 1998; Väliverronen 2001; Weingart 2012).

Rödder and Schäfer (2010) found some, but only limited, evidence for the mediatisation of science thesis. They argue that mediatisation is visible only in some areas of science, such as genetics and other research areas that have close connections to everyday life, such as health and medicine. Further, they concluded that, in the case of genetics, promotional discourses and intensive media coverage were present mainly in certain time periods, such as the early 2000s. Their conclusion was that 'media-induced structural change in science, though present, is much less pronounced than mediatization of other parts of society, most notably in politics and sports' (Rödder and Schäfer 2010: 260-261).

Thus, several studies have shown that there is a need to talk about science in the plural. The close connections to the media are typical only in some areas of research (Rödder and Schäfer 2010; Weingart 1998; Weingart and Pansegrau 1999). However, similar distinctions are not always used in conceptualising 'the media' in mediatisation research.

\section{The ambiguity of 'media' in mediatisation research}

What is meant by 'media' in the mediatisation discourses is far from clear. There is a tendency to lump together various conceptualisations of mediated communication from newspapers and broadcasting to networked social media - together under the label 'the media'. However, against the background of the rapid transformation of the media environment and the diversification of media technologies this kind of approach is no longer tenable (Adolf 2015: 6). This refers to the problem that 
'mediatization research is well theorized in many ways but is undertheorized when it comes to the concept of the media' (Andersson 2017: 44; see also Ampuja et al. 2014: 119; Kunelius 2014: 80).

The problem is that media and media agency are easily naturalised or essentialised, neglecting the wider social context and actors of mediated communication. The media should not be seen as a homogeneous bloc, not only because there are important distinctions between public service and commercial media, or 'quality' and 'tabloid' media, but also between professional news media and various social media. This argument is very relevant for mediatisation research, which has a strong focus on social change and transformation. Furthermore, it is important to analyse how 'different media's different technological affordances, institutional structure and different production logics contribute differently to changes in culture and society' (Ekström et al. 2016: 1109). Without specification there is a risk that one ascribes agency to the media and thereby neglects producers, investors, designers, peers and their role in the production of meaning (Gitelman 2006; Andersson 2017: 39). All these ambiguities contribute to the problem that many of the empirical studies of mediatisation 'are not concerned with the sociocultural processes through which media themselves (i.e., as technologies and cultural properties) become indispensable to various social actors' (Ekström et al. 2016: 1102). Another issue, raised by Banet-Weiser (2013), has been whether the institutional model developed by Mazzoleni and Schulz rests upon an overly functionalist understanding of the role of media in democratic politics and whether there is a need for consideration of the cultural dimensions of how citizens interact with mediated political communication.

These ambiguities with the media concept are partly related to another problem with mediatisation research, media-centredness (see, e.g., Ampuja et al. 2014: 122; Flew 2017) or media determinism (Andersson 2017: 47). For instance, simply looking at quantitative changes and more frequent interactions between politics and media institutions or between science and media institutions and actors does not reveal much about mediatisation of politics or mediatisation of science. It is too easy to see the media as a causal agent contributing to changes in politics or science. Studies on the relations between politics and the media have shown that these processes should not be seen simply as media-driven. The problem is that current simplified conceptualisations of mediatisation largely stem 'from the imaginaries of [the] mass media-era' (Kunelius and Reunanen 2016: 369).

The media environment has changed rapidly in the last 10-20 years, in technological, economic and social terms. In the current networked and hybrid (Chadwick 2013) media environment, the media themselves, and particularly journalism, seem to be in crisis, both economically and professionally (e.g., Waisbord 2013; Kunelius and Reunanen 2016). In this situation it is somewhat paradoxical to talk about the increasing power of news media and journalism vis-àvis other institutions. Furthermore, it is not viable to assume a single media logic acting as a causal agent of change. One potential solution to these problems with mediatisation is to look at different media in a larger context of the attention economy (e.g., Webster 2014; Wu 2016) and promotional culture (Wernick 1991; Davis 2013). 


\section{The rise of promotional culture: from 'publish or perish' to 'promote yourself or perish'}

Traditionally, news media have been important in steering public attention. However, their 'monopoly to manage public attention' (Kunelius and Reunanen 2016: 372) has been challenged in the last two decades. Journalism and news media seem to be in such a crisis that it has evoked tales of the 'end of journalism'. Furthermore, the erosion of professional practices in journalism has created intensive debates (see e.g., Davies 2008; Nerone 2015). This has made evident that the supposed 'media logic' is in fact intertwined with many other institutional logics in society, such as advertising, PR and marketing, and the logics of different institutional arenas it is interacting with. Thus, the analysis of mediatisation needs a broader perspective, which takes into account this multifaceted communication and media environment, and various actors and power brokers competing in the management of public attention and visibility.

The boundaries of journalism have become increasingly contested and porous. This is evident also in the relations between science and journalism. Critical evaluation of the mediatisation thesis points to the need to put also the study of the relations between science and the media into a larger social and cultural context. What is meant by mediatisation of science deals largely with the struggle for public legitimacy and the management of attention and visibility related to science. Several studies in science communication have pointed to the increasing use of marketing and PR strategies and discourses in 'selling science' (Nelkin 1995; Williams and Gajevic 2012). Promotional practices have become increasingly institutionalised in science-society relations (see e.g., Väliverronen 2001, 2004; Bauer and Bucchi 2007; Bauer 2008; Peters et al. 2008b; Maeseele 2013). The professionalisation of marketing practices and image management is changing the practices of science communication more towards science PR and 'PUS Inc'. (Bauer and Gregory 2007: 44). This is related to the increasing commercialisation of science. This affects not only the ways science is communicated in society but also other practices in science and knowledge production.

The concept of promotional culture provides a wider perspective to science-media relations. The term promotional culture was introduced by Andrew Wernick (1991) in the early 1990s to describe something that he called 'the semiotic colonisation' of culture by commercial advertising. Promotional texts were not limited to advertising and PR industries but were becoming a dominant form of symbolic expression in many social contexts, institutions and practices, such as politics and universities. Wernick's book included a chapter on the rise of 'the promotional university', in which he analysed the ways in which universities had been drawn into promotional logic, especially in student and staff recruitment, faculty career advancement and academic publishing.

Later, Aeron Davis (2013) developed the idea of promotional culture further. He extended the argument by demonstrating the ways in which promotional practices, not just advertising, shape society, organisations and individuals. Davis made a distinction between promotional industries and promotional intermediaries. The first describes industries such as advertising, $\mathrm{PR}$ and communication and the second active practices of individuals. He argued that society and its institutions have become 
more promotionally oriented and that individuals and organisations have grown to accommodate promotional discourse as a normal part of work and daily practices.

Compared to traditional advertising and marketing, which often meet public suspicion, new promotional practices provide more subtle forms of influence when they amalgamate into news stories and other communication forms. For Davis (2013: 198) promotion is 'the Trojan horse of marketization', introducing market principles into public sector institutions and everyday practices ('promote yourself'). Thus, living in promotional times is part of a larger cultural shift in society.

At the organisational, social and individual levels, promotion has seeped into all areas of society. Organisations, and those who work for them, have internalised, often unconsciously, various promotional responses and routines. Promotion is effective because it is not just top-down organisational communication but something which grows seemingly unintentionally also from below, with the help of or operational parameters by social media, such as sharing and likes. Thus, marketing and branding are much more effective, when they are not understood as a traditional topdown 'push communication'.

Competition between universities and marketing of research and education are nothing new for universities. What is new, according to Wernick (2006: 566) is 'the self-consciousness with which a university's corporate image has come to be managed, the administrative prominence this task assumes, and the objectification, and indeed monetization, of academic reputation itself as a brand'. This development has repercussions when the 'projected brand image feeds back into both product and its style of presentation' (ibid). The emergence of the new 'PR University' (Cronin 2016) intensifies investments in $\mathrm{PR}$ and marketing departments, which are related to the increasing use of metrics and the penetration of 'audit culture' in university practices.

Since the early 2000s, the amount of money spent on marketing and communications by colleges and universities in the US has rapidly increased. According to Hearn (2010), branding campaigns are not simply designed to help universities compete for the top students but to raise their profile in the public consciousness, bring in corporate sponsorship and endowment funds and communicate effectively with local communities and governments. As a result, the 'universities have begun to situate themselves at the intersection of the state and the market, enthusiastic participants in the blurring of boundaries between public and private sectors' (Hearn 2010: 208). Branding and marketing play a central role in universities' quest for favourable rankings, such as Times Higher Education and U.S. News and World Report. 'Paradoxically many universities use these categories for university adjudication established by these external publications as blueprints for their future' (Hearn 2015: 118). The centralisation of communicative processes in university marketing departments leads to new priorities in communicating research.

The increasing market orientation of universities and research organisations has been discussed and analysed by many scholars (e.g., Banet-Weiser 2013; Cronin 2016; Duffy and Pooley 2017; Hearn 2010, 2015; Marcinkowski et al. 2013; Marcinkowski and Kohring 2014; Whitmer 2019; Williams and Gajevic 2014). New ways of self-promotion have become an institutional practice, 'not only for fund raising, but also for student recruitment, career competition, grading, and academic 
publishing' (Maeseele 2013: 377). These new promotional practices are particularly increasing on various social media platforms. This in evident, for instance, on the 'Facebook for academics', Academia.edu. Academics are 'experiencing a parallel pressure to engage in self-promotional practices, particularly as universities become progressively more market-driven' (Duffy and Pooley 2017: 1).

Davies and Horst (2016) relate these new trends in science communication to the changing nature of science, referring to the concept of academic capitalism (e.g., Hackett 1990; Slaughter and Leslie 1997) and entrepreneurial university (e.g., Etzkowitz 1983 and 2003), discussed widely in the social studies of science. They argue, that together with the widely adopted New Public Management ideology in the universities this has contributed to the rise of corporate communication in universities. In this new commercially competitive environment for science communication, success in international rankings, prestigious grants, patents and agreements with distinguished institutions 'serve as shorthands of excellence and relevance, and are used as such in corporate communication to establish a strong brand' (Davies and Horst 2016: 115). The increasing role of corporate communication and PR in communicating science is also discussed by Trench (2017) in the context of professionalisation and training of science communicators through universities. Davis and Horst also point to the increasing role of corporate communication strategies and practices in communicating science which may contribute to the streamlining communication in universities and research organisations into one institution, one voice, policy and thus suppressing individual scientists' freedom of expression. Further, Marcinkowski and Kohring (2014: 5) define mediatisation of science in relation to the increasing commercialisation and promotional discourses of science. They propose that 'mediatization of academic institutions, understood as the adaptation to the criteria of public attention, is a PR strategy to enable universities to survive and thrive in an artificial competition for financial resources that was initiated in the political domain'. Further, they argue, that, the inherent logic PR communication represents a potential threat to the autonomy of scientific research, when 'being good' is replaced by just 'looking good' (p. 4).

\section{Promotional discourses and the erosion of science as 'public good'}

New promotional practices for managing visibility are not purely instrumental to science or science communication, but they are part of the marketisation of research and the higher education system in general. Sociologist Craig Calhoun (2006, 2009) has analysed the role of universities as public institutions and producers of 'public good'. Calhoun (2006) summed up the transformation of universities in the early $2000 \mathrm{~s}$ as a tension between 'excellence' and 'accessibility'. He pointed out that both excellence and accessibility are, in many ways, ideological concepts that are often spoken of as aspirations without further specification. It is therefore important to distinguish between practices that affect them in the development of universities and science.

Excellence in the language of higher education has become synonymous with quality. When it comes to universities and research, it has become customary to use 
the terms top university, top research or top researcher. These terms emerged from the ideology of competition and the proliferation of rankings and ratings. Excellence has become a way of branding universities, institutes, training programmes, research teams and individual researchers after the 'massification' of the university when titles and degrees have suffered from inflation.

For Calhoun, accessibility of the university refers specifically to two objectives. The first is the drive to disseminate scientific knowledge as widely as possible so that the benefits of universities and research can be shared across society. The second objective refers to elite universities' efforts to become more open so that students from lower socio-economic backgrounds can also enter.

There is a tension between these two goals, and many of the practices adopted by the academic world actually work against excellence and accessibility. The paywalls of commercial publishers and the reluctance of researchers to speak or write to anyone other than their colleagues limits the transparency of research. This is due to both traditional notions of academic independence as well as more recent rhetoric and evaluation practices of 'excellence'.

Traditionally, evaluations have directed researchers to publish in the most respected international journals and collect as many citations as possible for their publications. Newer evaluation practices in universities direct us in particular to strive for 'impact'. The competitive ideology of the audit culture directs universities and researchers to patent their work and work closely with companies to turn research data into private property. Alternatively, it guides researchers to produce mediafriendly stories about the practical benefits and impact of research.

Cronin (2016), who has studied promotional practices in UK universities, has argued that managing media visibility has become an important part of the new 'reputational capital' of universities, drawing from Bourdieu's (1986) symbolic capital, which is a representational form based on recognition and prestige that aims to secure a privileged position within the field. While for Bourdieu symbolic capital often draws on historically embedded privilege and prestige, Cronin has argued that the new reputational capital is based on a more fluid, fragile enactment of value that is tied to the shifting cultural economy of the media' (Cronin 2016: 399). Core elements of reputational capital are media stories about research and universities, and various metrics, not only research metrics such as the H-index but also 'softer' metrics of media coverage introduced after research impact has gained more prominence in research evaluations instead of traditional knowledge and historical prestige. As one press officer interviewed in Cronin's study put it: 'Reputation essentially is what do you want people to know about you' (p. 403). Universities subscribe to media monitoring services that provide information on how their promotional stories on new research, degrees, patents and other activities make their way into the media.

The role of 'reputational capital' has been heavily influenced by recent changes in the UK higher education sector, related to funding mechanisms, the introduction of differential tuition fees, new auditing processes and a change towards impact-based research evaluation. The promotional discourses and practices cultivating this new reputational capital illustrate that 'market processes and ideologies have been 
internalised in institutions and in a range of actors, including academic staff, managers and students' (Cronin 2016: 399). Thus, promotional practices are part of the marketisation of higher education. Universities adopt practices that are typical to market actors, thus changing the idea of university and research as a 'public good'. However, the promotional efforts of universities seem to be selective: brand narratives focus on the success of science and technology and not so much on social sciences and humanities. This may have effects on the funding priorities in research and education in the situation where visibility and 'impact' in the public sphere are considered an important part of success and reputation.

Promotional practices and streamlined communication practices may also reduce academic freedom and freedom of expression of researchers in public arenas. It has been shown that researchers working in state research institutes have more limited freedom. These limitations are often related to politically motivated control, such as in the violations against environmental researchers in the United States (Resnik 2008), Canada (Magnuson-Ford and Gibbs 2014; Amend and Barney 2016) and in Finland (Väliverronen and Saikkonen 2020). It seems that state research institutes are increasingly adopting quasi-entrepreneurial practices in science communication, as one organisation and one voice, which limits the freedom of individual researchers to speak up. These limitations are sometimes justified by market pressures. The leadership of state research institutes adopts and implements more centralised communication policies in the fear of losing important customers, if individual researchers make public commentaries that are not 'politically correct' (Väliverronen and Saikkonen 2020).

Recent studies have shown that universities, where researchers usually have enjoyed more freedom, are not immune to this development. New practices of branding and reputation management have introduced more streamlined corporate communication practices also to universities (Hearn 2015; Cronin 2016; Davies and Horst 2016), which poses a threat to academic freedom and freedom of expression. The centralisation of communicative practices in the universities leads to the imposition of strict rules for all university communication. The adoption of the corporative style in science communication makes communication a strategic activity, where 'every member of the organisation should internalise the house strategy so that all staff communicate the same basic message in harmony as a choir' (Karvonen (2011: 173). These practices limit the autonomy of departments and individuals within the university, thereby infringing on their academic freedom. Thus, promotional practices are not simply external or instrumental but also introduce ideological and cultural shifts to science communication practices and to the public role of science.

\section{Conclusion}

This chapter has investigated the mediatisation thesis adopted in media studies and science communication literature. It has argued that instead of subscribing to 'media power' or single 'media logic', we should see how media logics are in fact intertwined with many other institutional logics in society, such as commercialisation, PR 
and marketing. For this purpose, I have introduced the concept of promotional cultural to grasp some of the recent changes in science communication practices.

Further, dominant representations of science and technology should be theorised in relation to the transformations in the role of science and knowledge production in society, conceptualised, for instance, with the notions of entrepreneurial university, new public management and branding. We need more case studies on the promotional discourses of science and technology and their repercussions to knowledge production. Also, we need research on the broader effects the corporate style and practices in communicating science and expertise, such as the possible limitations to the freedom of expression for individual scientists.

\section{References}

Adolf, M., 2015. Unboxing mediatization theory status and future directions of mediatization research. Paper presented at New Directions in Mediatization Research: Culture, Conflict and Organizations, October 1-2, University of Copenhagen, pp. 1-10.

Altheide, D., Snow, R., 1979. Media Logic. Sage, Beverly Hills.

Altheide, D., 2013. Media logic, social control, and fear. Commun. Theory 23 (3), 223-238.

Amend, E., Barney, D., 2016. Getting it right: Canadian conservatives and the 'War on Science'. Can. J. Commun. 41 (1), 9-35.

Ampuja, M., Koivisto, J., Väliverronen, E., 2014. Strong and weak forms of mediatization theory: a critical review. Nordicom Rev. 35, 111-123.

Andersson, M., 2017. Mediatization from below. In: Driessens, O., Bolin, G., Hepp, A., Hjarvard, S. (Eds.), Dynamics of Mediatization. Transforming Communications - Studies in Cross-Media Research. Palgrave Macmillan, London.

Asp, K., 1986. Mäktiga massmedier: studier i politisk opinionsbildning. Akademilitteratur, Stockholm.

Asp, K., 1990. Medialization, media logic and mediarchy. Nordicom Rev. 11 (2), 47-50.

Banet-Weiser, S., 2013. Rate your knowledge: the branded university. In: McAllister, M.P., West, E. (Eds.), The Routledge Companion to Advertising and Promotional Culture. Routledge, London, pp. 298-312.

Bauer, M.W., 2008. Paradigm change for science communication: commercial science needs a critical public. In: Cheng, D., Claessens, M., Gascoigne, T., Metcalfe, J., Schiele, B., Shi, S. (Eds.), Communicating Science in Social Contexts. New Models, New Practices. Springer, Dordrecht, pp. 7-25.

Bauer, M.W., Bucchi, M. (Eds.), 2007. Journalism, Science and Society. Science Communication between News and Public Relations. Routledge, London and New York.

Bauer, M.W., Gregory, J., 2007. From journalism to corporate communication in post-war Britain. In: Bauer, M.W., Bucchi, M. (Eds.), Journalism, Science and Society. Science Communication between News and Public Relations. Routledge, London and New York, pp. 33-52.

Blumler, J.G., Esser, F., 2018. Mediatization as a combination of push and pull forces: examples during the 2015 UK general election campaign. Journalism 20 (7), 855-872.

Bucchi, M., 1998. Science and the Media. Alternative Routes in Scientific Communication. Routledge, London and New York.

Bucchi, M., Trench, B., 2014. Science communication research: themes and challenges. In: Bucchi, M., Trench, B. (Eds.), Routledge Handbook of Public Communication of Science and Technology (second ed.). Routledge, London and New York, pp. 1-14.

Calhoun, C., 2006. The university and the public good. Thesis Eleven 84 (1), 7-43.

Calhoun, C., 2009. Academic freedom: public knowledge and the structural transformation of the university. Soc. Res. 73 (2), 561-598. 
Chadwick, A., 2013. The Hybrid Media System: Politics and Power. Oxford University Press, Oxford.

Corner, J., 2018. 'Mediatization': media theory's word of the decade. Media Theory 2 (2), 79-90.

Couldry, N., Hepp, A., 2013. Conceptualizing mediatization: contexts, traditions, arguments. Commun. Theory 13 (3), 191-202.

Cronin, A.M., 2016. Reputational capital in "the PR University": public relations and market rationalities. J. Cult. Econ. 9 (4), 396-409.

Danermark, B., Ekström, M., Jacobsel, L., Ekström, M., 2002. Explaining Society: Critical Realism in the Social Sciences. Routledge, London.

Davies, N., 2008. Flat Earth News. Chatto and Windus, London.

Davis, A., 2013. Promotional Cultures. Polity Press, Cambridge.

Davies, S. R., Horst, M., 2016. Science Communication - Culture, Identity, Citizenship. Palgrave Macmillan, London.

Deacon, D., Stanyer, J., 2014. Mediatization: key concept or conceptual bandwagon? Media, Cult. Soc. 36 (7), 1032-1044.

Deacon, D., Stanyer, J., 2015. 'Mediatization and' or 'mediatization of? A response to Hepp et al. Media Cult. Soc. 37 (4), 655-657.

Duffy, B.E., Pooley, J.D., 2017. "Facebook for Academics": the convergence of self-branding and social media logic on Academia.edu. Soc. Media Soc. 3 (1), 1-11.

Ekström, M., Fornäs, J., Jansson, A., Jerslev, A., 2016. Three tasks for mediatization research: contributions to an open agenda. Media Cult. Soc. 38 (7), 1090-1108.

Esser, F., Strömbäck, J. (Eds.), 2014. Mediatization of Politics. Understanding the Transformation of Western Democracies. Palgrave Macmillan, New York.

Etzkowitz, H., 1983. Entrepreneurial scientists and entrepreneurial universities in American academic science. Minerva 21 (2), 198-233.

Etzkowitz, H., 2003. Innovation in innovation. The triple helix of university-industrygovernment relations. Soc. Sci. Inf. 42, (3), 293-337.

Flew, T., 2017. The "theory" in media theory. Media Theory 1 (1), 43-56.

Franzen, M., Weingart, P., Rödder, S., 2012. Exploring the impact of science communication on scientific knowledge production: an introduction. In: Rödder, S., Franzen, M., Weingart, P. (Eds.), The Sciences' Media Connection-Communication to the Public and its Repercussions. Sociology of the Sciences Yearbook 28. Springer, Dordrecht, pp. 3-14.

Gitelman, L., 2006. Always Already New: Media, History, and the Data of Culture. The MIT Press, Cambridge MA.

Gregory, J., Miller, S., 1998. Science in Public: Communication, Culture, and Credibility. Plenum Trade, London and New York.

Hackett, E.J., 1990. Science as a vocation in the 1990s: the changing organizational culture of academic science. J. High. Educ. 61, 241-279.

Hearn, A., 2010. Through the looking glass: the promotional University 2.0. In: Aronczyk, M., Powers, D. (Eds.), Blowing Up the Brand: Critical Perspectives on Promotional Culture. Peter Lang, New York, pp. 197-219.

Hearn, A., 2015. The politics of branding in the new university of circulation. Int. Stud. Manag. Organ. 45 (2), 114-120.

Hepp, A., 2013a. The communicative figurations of mediatized worlds: mediatization research in times of the 'mediation of everything'. Eur. J. Commun. 28 (6), 615-629.

Hepp, A., 2013b. Cultures of Mediatization. Polity Press, Cambridge.

Hepp, A., Hjarvard, S., Lundby, K., 2010. Mediatization - empirical perspectives: an introduction to a special issue. Communications 35 (3), 223-228.

Hepp, A., Hjarvard, S., Lundby, K., 2015. Mediatization: theorizing the interplay between media, culture and society. Media Cult. Soc. 37 (2), 314-324.

Hepp, A., Hasebrink, U., 2018. Researching transforming communications in the time of deep mediatization. In: Hepp, A., Breiter, A., Hasebrink, U. (Eds.), Communicative 
Figurations: Transforming Communications in Times of Deep Mediatization. Springer International Publishing AG, Switzerland, pp. 15-48.

Hjarvard, S., 2008. The mediatization of society: a theory of the media as agents of social and cultural change. Nordicom Rev. 29 (1), 105-134.

Hjarvard, S., 2012. Doing the right thing. Media and communication studies in a mediatized world. Nordicom Rev. Supplement, 33 (1), 27-34.

Hjarvard, S., 2013. The Mediatization of Culture and Society. Routledge, London; New York.

Hjarvard, S., 2014. Mediatization and cultural and social change: an institutional perspective. In: Lundby, K. (Ed.), Mediatization of Communication. Handbook of Communication Science 21. De Gruyter, Berlin, pp. 199-226.

Karvonen, E., 2011. Tieteen ja liiketoiminnan periaatteet törmäyskurssilla: sensuroiko VTT tutkijoitaan? Media Viestintä 34 (1), 163-175.

Krotz, F., 2009. Mediatization: a concept with which to grasp media and societal change. In: Lundby, K. (Ed.), Mediatization. Concept, Changes, Consequences. Peter Lang, New York, pp. 21-40.

Krotz, F., 2014. Media, mediatization and mediatized worlds: a discussion of the basic concepts. In: Hepp, A., Krotz, F. (Eds.), Mediatized Worlds: Culture and Society in a Media Age. Palgrave Macmillan, Basingstoke, pp. 72-87.

Kunelius, R., 2014. Climate change challenges: an agenda for de-centered mediatization research. In: Lundby, K. (Ed.), Mediatization of Communication. De Gruyter, Berlin, pp. 63-86.

Kunelius, R., Reunanen, E., 2012. The medium of the media: journalism, politics, and the theory of 'mediatisation'. Javnost 19 (4), 5-24.

Kunelius, R., Reunanen, E., 2016. Changing power of journalism: the two phases of mediatization. Commun. Theory 26, 369-388.

Livingstone, S., 2009. On the mediation of everything. J. Commun. 59 (1), 1-18.

Livingstone, S., Lunt, P., 2014. Mediatization: an emerging paradigm for media and communication research? In: Lundby, K. (Ed.), Mediatization of Communication. De Gruyter, Berlin, pp. 703-724.

Lundby, K., 2009. Introduction: 'Mediatization' as key. In: Lundby, K. (Ed.), Mediatization. Concept, Changes, Consequences. Peter Lang, New York, pp. 1-18.

Lundby, K., 2014. Introduction: Mediatization of communication. In: Lundby, K. (Ed.), Mediatization of Communication. De Gruyter, Berlin, pp. 3-38.

Lunt, P., Livingstone, S., 2016. Is 'mediatization' the new paradigm for our field? A commentary on Deacon and Stanyer $(2014,2015)$ and Hepp, Hjarvard and Lundby (2015). Media Cult. Soc. 38 (3), 462-470.

Maeseele, P., 2013. On media and science in late modern societies. In: Cohen, E. (Ed.), Communication Yearbook 37. Routledge, New York, pp. 155-181.

Magnuson-Ford, K., Gibbs, K., 2014. Can Scientists Speak? Grading Communication Policies for Federal Government Scientists. Evidence for Democracy and Simon Fraser University. Available from: https://evidencefordemocracy.ca/sites/default/files/reports/Can\%20Scien tists\%20Speak_.pdf (accessed 20May2020).

Marcinkowski, F., Kohring, M., Fürst, S., Friedrichsmeier, A., 2013. Organizational influence on scientists' efforts to go public: an empirical investigation. Sci. Commun. 36, 56-80.

Marcinkowski, F., Kohring, M., 2014. The changing rationale of science communication: a challenge to scientific autonomy. JCOM J. Sci. Commun. 13 (3), C04.

Martin-Barbero, J., 1993. Communication, Culture and Hegemony: From Media to Mediation. Sage Publications, London.

Mazzoleni, G., Schulz, W., 1999. Mediatization of politics: a challenge for politics? Polit Commun. 16, 247-261.

Nelkin, D., 1995. Selling Science. How The Press Covers Science and Technology. W.H. Freeman and Company, Revised edition. New York. 
Nerone, J., 2015. Journalism's crisis of hegemony. Javnost Public. 22 (4), 313-327.

Nowak-Teter, E., 2019. Mediatization: conceptual developments and research domains. Sociol. Compass 13 (4), 1-10.

Peters, H.P., Heinrichs, H., Jung, A., Kallfass, M., Petersen, I., 2008a. Medialization of science as a prerequisite of its legitimation and political relevance. In: Cheng, D., Claessens, M., Gascoigne, T., Metcalfe, J., Schiele, B., Shi, S. (Eds.), Communicating Science in Social Contexts: New Models, New Practices. Springer, Dordrecht, pp. 71-92.

Peters, H.P., Brossard, D., de Cheveigné, S., Dunwoody, S., Kallfass, M., Miller, S., Tsuchida, S., 2008b. Science-media interface: it's time to reconsider. Sci. Commun. 30 (2), 266-276.

Peters, H.P., 2012. Scientific sources and the mass media: forms and consequences of medialization. In: Rödder, S., Franzen, M., Weingart, P. (Eds.), The Sciences' Media Connection -Public Communication and its Repercussions. Sociology of the Sciences Yearbook 28. Springer, Dordrecht, pp. 217-239.

Resnik, D.B., 2008. Freedom of speech in government science. Issues Sci. Technol. 24 (2), 31-34.

Rödder, S., 2009. Reassessing the concept of a medialization of science: a story from the "book of life". Public Underst. Sci. 18 (4), 452-463.

Rödder, S., Schäfer, M., 2010. Repercussion and resistance: an empirical study in the interrelation between science and mass media. Communications 35, 249-267.

Schäfer, M.S., 2009. From public understanding to public engagement: an empirical assessment of changes in science coverage. Sci. Commun. 30 (4), 475-505.

Silverstone, R., 2005. The sociology of mediation and communication. In: Calhoun, C., Rojek, C., Turner, B. (Eds.), The Sage Handbook of Sociology. Sage, London, pp. 188-207.

Slaughter, S., Leslie, L., 1997. Academic Capitalism - Politics, Policies and the Entrepreneurial University. The Johns Hopkins University Press, Baltimore.

Strömbäck, J., 2011. Mediatization and perceptions of the media's political influence. J. Stud. 12 (4), 423-439.

Strömbäck, J., Esser, F., 2009. Shaping politics: mediatization and media interventionism. In: Lundby, K. (Ed.), Mediatization. Concept, Changes, Consequences. Peter Lang, New York, pp. 205-224.

Strömbäck, J., Dimitrova, D., 2011. Mediatization and media interventionism: a comparative analysis of Sweden and the United States. Int. J. Press/Politics 16 (1), 30-49.

Strömbäck, J., Esser, F., 2014. Mediatization of politics: transforming democracies and reshaping politics. In: Lundby, K. (Ed.), Mediatization of Communication. De Gruyter, Berlin, pp. 375-404.

Thompson, J.B., 1995. The Media and Modernity: A Social Theory of the Media. Polity Press, Cambridge.

Trench, B., 2012. Scientists' blogs: glimpses behind the scenes. In: Rödder, S., Franzen, M., Weingart, P. (Eds.), The Sciences' Media Connection - Public Communication and its Repercussions. Sociology of the Sciences Yearbook 28. Springer, Dordrecht.

Trench, B., 2017. Universities, science communication and professionalism. JCOM - J. Sci. Commun. 16 (5), 1-8.

Väliverronen, E., 2001. From mediation to mediatization: the new politics of communicating science and biotechnology. In: Kivikuru, U., Savolainen, T. (Eds.), The Politics of Public Issues. Department of Communication, University of Helsinki, pp. 157-178.

Väliverronen, E., 2004. Stories of the 'medicine cow': Representations of future promises in media discourse. Public Underst. Sci. 13, 363-377.

Väliverronen, E., Saikkonen, S., 2020. Freedom of expression challenged: Scientists' perspectives on hidden forms of suppression and self-censorship.Science, Technology \& Human Values. Doi: 10.1177/0162243920978303.

Waisbord, S., 2013. Re-inventing Professionalism: Journalism and News in Global Perspective. Polity, Cambridge. 
Webster, J.G., 2014. The Marketplace of Attention. How Audiences Take Shape in a Digital Age. MIT Press, Cambridge, MA \& London.

Weingart, P., 1998. Science and the media. Res. Policy 27 (9), 869-879.

Weingart, P., 2001. Die Stunde der Wahrheit? Zum Verhältnis der Wissenschaft zu Politik, Wirtschaft und Medien in der Wissensgesellschaft. Velbrück Wissenschaft, Weilerswist.

Weingart, P., 2012. The lure of the mass media and its repercussions on science. In: Rödder, S., Franzen, M., Weingart, P. (Eds.), The Sciences' Media Connection -Public Communication and its Repercussions. Sociology of the Sciences Yearbook 28. Springer, Dordrecht, pp. 17-32.

Weingart, P., Pansegrau, P., 1999. Reputation in science and prominence in the media: the Goldhagen Debate. Public Underst. Sci. 81, 1-16.

Wernick, A., 1991. Promotional Culture: Advertising, Ideology and Symbolic Expression. Sage, London.

Wernick, A., 2006. Rebranding Harvard. Theory Cult. Soc. 23 (2-3), 566-567.

Whitmer, J.M., 2019. You are your brand: self-branding and the marketization of self. Sociology Compass 13 (3), 1-10.

Williams, A., Gajevic, S., 2012. Selling Science?. J. Stud. 14 (4), 507-522.

Wu, T., 2016. The Attention Merchants. Knopf, New York. 